\title{
KEBERAGAMAAN PEREMPUAN KEPALA KELUARGA DI PONTIANAK TIMUR KALIMANTAN BARAT
}

\author{
Juniawati
}

\begin{abstract}
Abstrak
Tulisan ini membuka pengetahuan kita atas realita keberagamaan perempuan kepala keluarga di Pontianak Timur Kalimantan Barat yang dihadapkan dengan berbagai permasalahan. Ditengah-tengah tuntutan kebutuhan yang hidup yang terus bertambah, perempuan kepala keluarga menanggung beban berat sebagai single parent, ditinggal pergi suami dengan dalih menjadi TKI atau ditinggal tanpa status yang jelas. Ditambah berbagai keterbatasan --tingkat pendidikan yang terbatas, kendala ekonomi yang yang tak terelakkan memaksa perempuan kepala keluarga bekerja sebagai buruh lepas.

Pendekatan kualitatif dan metode deskriptif dengan wawancara mendalam, observasi non partisipan penulis memperoleh gambaran komprehensif yakni peran orang tua dalam keluarga mampu menanamkan keyakinan dan harapan akan masa depan melalui informasi nilai-nilai agama, peran lambaga dakwah seperti majelis taklim dan berinteraksi dalam kegiatan masjid di lingkungan tempat tinggal, adalah menjadi upaya terdekat dalam rangka mencari, meningkatkan dan memelihara pengetahuan ke-Islaman sehingga memberikan pengaruh positif kepada sikap keberagamaan baik bagi perempuan kepala keluarga sebagai individu maupun bagi dari masyarakat.
\end{abstract}

Kata kunci: Perempuan kepala Keluarga, keberagamaan, peran orang tua, lembaga dakwah

\section{A. Latar Belakang Masalah}

Potret perempuan tidak jarang identikkan dengan kaum terpinggir, yang miskin dan terisolir dari peradaban. Stigma ini melekat lantaran perempuan dipandang sebagai pelengkap saja (subordinat). Tak jarang pula stereotype perempuan dalam berbagai kehidupan ini dipandang sebelah mata dan perempuan lebih dipandang sebagai pelaku yang kerjaannya hanya di seputar wilayah domestik, tidak lebih.

Partini (2008) menyatakan bahwa data 17 persen perempuan menjadi tokoh utama dalam rumah tangga sebagai kepala rumah tangga yang bekerja menghidupi keluarganya (www.ugm.co.id). Hal ini disebabkan lantaran laki-laki dalam kondisi miskin dapat melepaskan tanggungjawabnya sebagai kepala keluarga. Akibatnya perempuan diceraikan atau ditinggalkan tanpa status yang jelas. Pada tahun 2010, dalam catatan Biro Pusat Statistik (BPS 2008) terdapat 65 juta keluarga di Indonesia. Dari keluargakeluarga tersebut, 14\% (9 juta) dikepalai oleh perempuan (Hartanto, Wendy dalam Cate Sumner 2010). Laporan pemberitaan lokal di Kalimantan Barat khusunya di 
Pontianak tahun 2015 terdapat 2.450 wanita yang berstatus janda dan mayoritas usia antara 17-35 tahun. Sisanya, 1.017 orang menjanda pada usia 36-40 tahun (tribunnews.com). Dari sumber lain pada 2017 juga mengungkap data dari pengadilan Agama kelas $1 \mathrm{~A}$, bahwa alasan perceraian di Pontianak karena tidak bertanggungjawab, meninggalkan kewajiban ekonomi, tidak ada keharmonisan dll (www.equator.com). Penulis ketengahkan di sini, perempuan kepala keluarga tidak hanya disebabkan perceraian, juga perempuan yang ditinggal mati suaminya karena konflik atau karena sakit. Para istri yang ditinggal pergi suaminya bekerja di luar daerah, secara legal status mereka masih sebagai istri tapi secara ekonomi mereka miskin dan penghasilan suami tidak cukup untuk dikirimkan ke keluarga dan habis dipakai untuk kebutuhannya sendiri, sehingga perempuan menjadi penanggungjawab penuh kegiatan dan kebutuhan hidup sehari-hari. Perempuan karena poligami yang kerap mendapat perlakuan kekerasan secara fisik maupun psikologis dari suami, ditambah lagi dengan sikap suami yang meninggalkan istri dan berpindah ke tempat lain. Hal ini mendorong perempuan untuk diam dan memilih menjadi kepala keluarga. Dari definisi ini jelas bahwa perempuan kepala keluarga pencari nafkah utama dan tanggungjawab utama berada di tangan perempuan. (pekka.or.id, 2013)
Berdasarkan data pengurus PEKKA terdapat 1.147 perempuan kepala keluarga di Kalimantan Barat yang sebagian besar tinggal di kota Pontianak (sumber: pengurus PEKKA, 2012). Kondisi perempuan sebagai kepala keluarga di kota Pontianak sepenuhnya menyandang status perkawinan yang tidak jelas atau digantung oleh suami. Akibat perceraian dan ditinggal mati oleh suaminya. Sebagian besar kehidupan perempuan kepala keluarga yang ada di kota Pontianak ini mesti menanggung kebutuhan hidup sehari-hari dan sepenuhnya menjadi tulang punggung keluarga. Menurut Kholila (2012) pengurus Serikat perempuan kepala keluarga Kalimantan Barat, perempuan kepala keluarga mesti membiayai sepenuhnya sekolah anak-anak mereka, memenuhi kebutuhan sehari-hari orang tua mereka dan orang tua dari suami mereka, sebab sebagian ada yang masih bersama dengan orang tuanya atau dengan keluarga dari suami mereka yang ditinggal tanpa tanggungjawab. Dalam kajian Siska Sasmita (2011) mengenai peran perempuan Suku Minangkabau yang menjadi kepala keluarga di Kecamatan Padang Timur. Diketahui, perempuan menjadi aktor dominan dalam pemenuhan kebutuhan keluarga meski dengan banyaknya keterbatasan perempuan yang disandangnya sebagai kepala keluarga, diantaranya kesulitan akses sosial dalam ekonomi dan peran-perannya di masyarakat namun tidak menyurutkan perempuan untuk 
berupaya secara maksimal menjadi tulang punggung sehingga bekerja dengan caracara negatif menjadi pilihan yang tidak bisa dihindari. Dalam kesempatan ini, kajian ini bertujuan menggambarkan sikap keberagamaan perempuan kepala keluarga, faktor yang mempengaruhi kehidupan keberagamaan perempuan kepala keluarga di Pontianak Timur dan upaya yang dilakukan perempuan kepala keluarga menjaga keberagamaannya.

\section{B. Keberagamaan}

Secara bahasa, istilah
keberagamaan berasal dari kata
beragama, berasal dari kata religio. Istilah
agama sendiri berarti ikatan relasi-relasi
sosial antar individu. Konsep agama
dalam pengertian ini mengandung makna bahwa agama dapat memberikan harapan, ganjaran dan dukungan (Bryan S. Turner, 2012). Kata beragama memiliki makna memeluk atau menjalankan suatu agama. Selanjutnya, kata beragama mengalami konfiksasi ke-an, sehingga jadi keberagamaan. Kata keberagamaan memiliki makna suatu hal atau keadaan, tepatnya hal atau keadaan seseorang dalam beragama. Makna tersebut sebagaimana seperti yang tercantum dalam Kamus Umum Bahasa Indonesia (Poerwadarminta, 1978). Makna lain yang mendalam mengenai agama yakni:

(1) Agama simbol yang gunanya;

(2) Membentuk mood dan motivasimotivasi yang begitu kuat, melingkupi dan bertahan lama dalam diri manusia dengan;

(3) Memformulasikan konsepsi-konsepsi tatanan umum eksistensi dan;

(4) Menyelebungi konsep-konsep tersebut dengan semacam aura faktualitas sehingga

(5) Mood dan motivasi-motivasi secara unik suntuk dapat ditangkap sebagai sesuatu yang realitistis (Berger, 1969 dalam Bryan S. Turner, 2012).

\section{Faktor-faktor Keberagamaan}

Keberagamaan adalah sebagai perilaku yang bersumber langsung atau tidak kepada nash. Nash merupakan sumber ajaran yang berupa teks baik lisan maupun tulisan yang sakral dan menjadi sumber rujukan bagi pemeluk agama. Untuk agama Islam nash adalah Al-Qur'an dan Al-Hadist Jalaluddin Rahmat (1989). Istilah keberagamaan diartikan sebagai cara atau sikap seseorang dalam memeluk atau menjalankan agamanya. Empat faktor keberagamaan: faktor pengaruh sosial, berbagai pengalaman, faktor kebutuhan, proses pemikiran

Faktor sosial yang memiliki beberapa unsur juga dinyatakan oleh Thouless (2000) yang dikutip oleh Nur Azizah (2006) mengemukakan empat faktor yang mempengaruhi perkembangan religiusitas, yaitu: (1) Faktor sosial, meliputi semua pengaruh sosial seperti; pendidikan dan pengajaran dari orangtua, tradisi-tradisi dan tekanan-tekanan sosial, 
(2) Faktor alami, meliputi moral yang berupa pengalaman-pengalaman baik yang bersifat alami, seperti pengalaman konflik moral maupun pengalaman emosional, (3) Faktor kebutuhan untuk memperoleh harga diri dan kebutuhan yang timbul karena adanya kematian, dan (4) Faktor intelektual yang menyangkut proses pemikiran verbal terutama alam pembentukan keyakinan-keyakinan agama. Berikutnya, dalam sebuah kajian dikatakan bahwa unsur significant others membantu membentuk jiwa keagamaan seseorang dan memiliki peran penting dalm kehidupan. Disebutkan dalam penelitian Sekar Ayu Aryani (2015) significant others dalam penelitiannya adalah faktor guru, orang tua dan teman sebaya berperan dalam menanamkan dan membentuk keberagamaan.

Faktor pendidikan dalam hal ini orang tua dan keluarga merupakan Organ terpenting dalam membentuk generasi. Ajaran agama pertama kali diajarkan adalah orang tua. Dalam Islam, kehidupan keluarga menjadi fase sosialisasi awal bagi pembentukan keagamaan seseorang. Pengaruh kedua orang tua terhadap perkembangan jiwa sangat menentukan. Keluarga dinilai sebagai faktor yang paling dominan dalam meletakkan dasar bagi perkembangan jiwa keagamaan. Dalam keluarga diajarkan mencintai, hubungan sosial, menghormati, mengabdi, menaruh perhatian, dan taat serta melaksanakan nilai-nilai moral, (Haitami Salim, 2013).
Adapun hal-hal yang dibangun dalam keluarga menurut Wajidi Sayadi (2014) seperti berikut ini:

Membangun Hati. Artinya Ibadah, saling mencintai, menghargai, menfungsikan tanggungjawab

Membangun akal. Pendidikan, memahami tugas dan tanggungjawab, melindungi,

Sacara fisik. Sehat, Keterampilan, rezki halal, ekonomi

\section{Lingkungan. Pergaulan Sosial}

\section{Fungsi Agama}

Diantara fungsi agama sebagaimana yang disebut pakar sosiologi adalah fungsi edukatif, penyelamatan, pengawasan sosial, pemupuk persaudaraan dan fungsi transformatif. Fungsi edukatif adalah mengajarkan nilainilai otoritatif tentang makna dan tujuan hidup, mengenalkan sang pencipta, tentang ganjaran baik dan buruk atas perbuatan (Hendropuspito, O.C, 1983) dalam Harjani Hefni (2012). Bagi masyarakat Indonesia pentingnya agama sangat berarti, sehingga dalam menjadi sandaran kehidupan berbangsa dan bernegara seperti yang termaktub pada Bab XI pasal 29 (1) dan (2) UUD 1945 yang menegaskan bahwa negara berdasarkan atas Ketuhanan yang Maha Esa dan negara menjamin kemerdekaan tiap-tiap penduduk untuk memeluk agamanya masing-masing dan untuk beribadat menurut agama dan kepercayaannya itu. Al-qur'an Q.S. Al- 
Hujuraat 49:13, (Departemen agama RI. 1997):

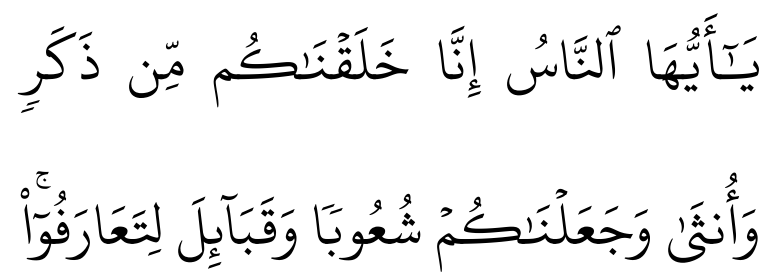

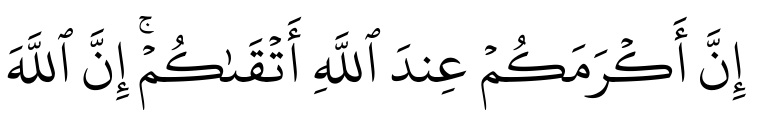

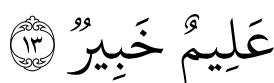

"Hai manusia, sesungguhnya Kami menciptakan kamu dari seorang laki-laki dan seorang perempuan dan menjadikan kamu berbangsa-bangsa dan bersuku-suku supaya kamu saling kenal-mengenal. Sesungguhnya orang yang paling mulia diantara kamu disisi Allah ialah orang yang paling taqwa diantara kamu. Sesungguhnya Allah Maha Mengetahui lagi Maha Mengenal"

Islam telah memberikan pandangan terhadap keberadaan dan kedudukan perempuan. Islam sangat memberikan kesempatan kepada perempuan untuk mengembangkan dirinya sebagai sumber daya manusia di tengahtengah masyarakat dan telah secara jelas mengajarkan adanya persamaan antara manusia laki-laki dan perempuan maupun antar bangsa, suku dan keturunan. Yang membedakan mereka terutama adalah tingkat ketaqwaannya.

Untuk mewujudkan satuan perilaku beragama diperlukan suatu proses panjang ynag menyangkut dimensi kemanusiaan baik pada aspek kejiwaan, perorangan disimpulkan dari sifat ajaran agama yang menjangkau keseluruhan hidup manusia, karena manusia memiliki dimensi kejiwaan perorangan atua kelompok. Praktik agama /syariah mengacu kepada seberapa tingkat kepatuhan muslim, dalam mengerjakan kegiatan ritual yang dianjukan oleh agama.

Maka dalam hal ini dimensi peribadatan keber-Islaman ditunjukkan dengan pelaksanaan sholat, puasa, haji, membaca Qur'an, doa, dzikir dll. Seperti pelaksanaan Sholat, sholat adalah rukun Islam yang kedua, Sholat menurut lughot atau bahasa adalah do'a. Sholat dimulai takbir dan disudahi dengan memberi salam. Allah SWT berfirman Q.S. Al-Ankabut: 45, (Departemen agama RI. 1997):
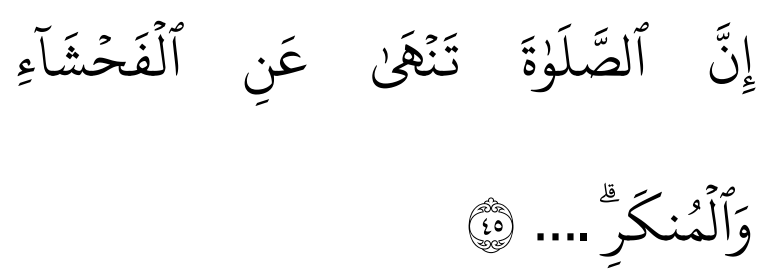

".... dan tegakkanlah shalat, karena shalat itu mencegah diri dari perbuatan yang keji dan mungkar.

Selain itu, tujuan utama dari perintah sholat adalah untuk mengingat Allah sebagaimana tercermin dalam surat Thaha: 14, (Departemen agama RI. 1997)

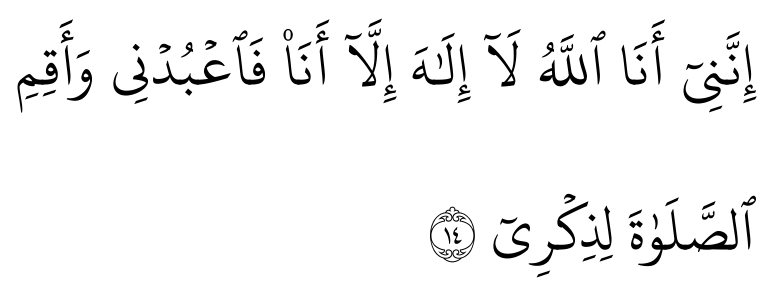

Artinya: 
"Sungguh, Aku ini adalah Allah, tidak ada Tuhan selain Aku, maka sembahlah Aku dan dirikanlah sholat untuk mengingat Aku"

Sementara puasa merupakan perisai dari segala bentuk perbuatan keji. Sebagaimana Hadis yang diriwayatkan oleh Abu Hurairah R.A yang artinya:

"Abu Hurairah R.A berkata: Rasulullah SAW Bersabda: Puasa itu bagaikan perisai (dinding) maka jangan berkata keji atau berlaku masa bodoh dan sebagainya. Dan jika ada orang mengajak berkelahi atau memaki hendaknya berkata: Aku puasa, aku puasa. Demi Allah yang jiwaku ada di tangan-Nya bau mulut orang yang berpuasa itu lebih harum di sisi Allah dari bau kasturi. Dia meninggalkan makan, minum dan syahwatnya karena-Ku, puasa itu untuk-Ku dan Akulah yang akan memberi pahalanya, dan biasa tiap hasanat sepuluh kali lipat gandanya"

\section{Metodologi Penelitian}

Penelitian ini menggunakan pendekatan kualitatif dengan metode deskriptif. Penting disini adalah makna dan mementingkan penafsiran; merujuk kepada makna, konsep, definisi, ciri-ciri dan metafora, dan lebih jauh penelitian kualitatif membantu usaha penyelidikan untuk melihat apa, bagaimana, kapan dan dimana sesuatu kajian dilakukan. Metode deskriptif digunakan untuk menjelaskan faktor-faktor keberagamaan perempuan. Pengumpulan data dilakukan dengan observasi dan wawancara mendalam disertai dokumentasi. Wimmer dan Dominick (2000) Rachmat Kriyantono mengarahkan peneliti melakukan "filling system" artinya data mentah hasil observasi kemudian dikatagorisasi setelah itu diinterpretasi dengan memadukan konsep-konsep atau teori tertentu (Rachmat Kriyantono, 2008) diikuti dengan wawancara. Susan Stainback (1998) dalam Sugiyono (2011) bahwa: interviewing provide the reseacher a means to gain a deeper understanding of how the participant interpret a situation or phenomenon than can be gained through obcervation alon. Wawancara mendalam mengarahkan pada informasi mengenai pendapat, tanggapan, keyakinan, perasaan mengenai topik yang ditanyakan kepada orang yang diwawancara. Studi dokumen diungkapkan Bogdan (seperti dikutip Sugiyono) "in most tradition of qualitative research, the phrase personal document is used broadly lo refer to any first person narrative produce by an individual which describes his or her own actions, experience, and beliefs". Teknik Analisis data dalam kajian ini merujuk pada (Rachmat Kriyantono, 2006), yakni: pengumpulan data, klasifikasi data dan interpretasi data (Rachmat Kriyantono, 2006).

Berikut langkah analisis penelitian ini adalah sebagai berikut:

\section{Bagan Analisis Penelitian}

Data Empiris Tataran Konseptual

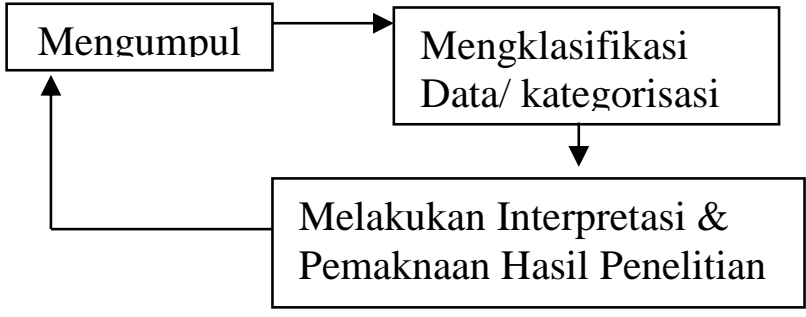

Rachmat Kriyantono, 2006 


\section{Hasil penelitian}

1. Kondisi sosial Perempuan Kepala Keluarga di Pontianak Timur

Penduduk di Pontianak Timur 92.941 orang yang notabene beragama Islam berjumlah 82.287 orang (dokumen Kecamatan Pontianak Timur tahun 2014) Berdasarkan hasil yang terjadi di kota Pontianak, ditemukan data bahwa sebagian besar perempuan kepala keluarga adalah muslim. Perempuan kelapa keluarga di Pontianak Timur dalam kajian ini adalah:

1. Perempuan yang berdomisili di Kecamatan Pontianak Timur

2. Perempuan yang berstatus janda yang ditinggal mati suaminya karena konflik atau karena sakit,

3. Perempuan yang ditinggal pergi suaminya bekerja di luar daerah, secara legal status mereka masih sebagai istri tapi secara ekonomi mereka miskin dan penghasilan suami tidak cukup untuk dikirimkan ke keluarga dan habis dipakai untuk kebutuhannya sendiri, sehingga perempuan menjadi penanggungjawab penuh kegiatan dan kebutuhan hidup sehari-hari.

4. Perempuan karena poligami yang kerap mendapat perlakuan kekerasan secara fisik maupun psikologis dari suami, ditambah lagi dengan sikap suami yang meninggalkan istri dan berpindah ke tempat lain.

Perempuan kepala keluarga di Kecamatan Pontianak Timur umumnya ditinggal suami karena meninggal dunia karena sakit dan usia yang telah lanjut. Ada juga perempuan kepala keluarga dengan status bercerai. Pekerjaan suami dari perempuan kepala keluarga umumnya adalah pekerja lepas, seperti sopir, penambang spit motor, montir motor atau mobil dan buruh pelabuhan. Namun ada juga yang pegawai negeri sipil seperti pegawai Satpol PP. Selain itu, terdapat juga suami dari perempuan kepala keluarga yang semasa hidupnya sebagai pengurus lembaga swadaya masyarakat dan pengurus masjid Jami'. Sebagian besar, kehidupan rumah tangga perempuan kepala keluarga telah ditnggal pergi (meninggal dunia/bercerai) di atas 5 tahun terakhir. Sumber masalah perceraian disebabkan berbagai persoalan, yakni masalah ekonomi. Meski dengan kondisi ekonomi yang pas-pasan sepeninggalan pasangan hidup (suami) bagi perempuan kepala keluarga tidak menjadi alasan perempuan untuk tidak meneruskan kehidupan mereka dengan anggota keluarga yang ditinggalkan. Pekerjaan sebagai tukang cuci, penjual makanan dan minuman di depan rumah atau menjadi buruh lepas, menjadi guru mengaji dan menjadi karyawan toko sembako, jual beli emas adalah pekerjaan perempuan kepala keluarga. Hasil yang diperoleh berkisar 300600 ribu perbulan untuk menghidupi keluarganya.

Kesulitan akses pekerjaan yang layak ini, dipengaruhi oleh rendahnya pengetahuan yang dimiliki lantaran hanya 
tamatan SD. Kondisi ini bukanlah seperti yang diinginkan perempuan, namun pada kenyataannya sebagian perempuan kepala keluarga berasal dari keluarga kurang mampu atau ekonomi menengah ke bawah dan mempunyai jumlah saudara yang banyak, akibatnya orang tua dari perempuan kepala keluarga tidak dapat memberikan pendidikan yang maksimal kepada perempuan kepala keluarga sehingga mereka tidak dapat melanjutkan pendidikan ke jenjang yang lebih tinggi. Di sisi lain, kondisi keluarga yang cukup banyak (mempunyai anak lebih dari 2 hingga 8) kurang memungkinkan untuk perempuan kepala keluarga dapat bergerak leluasa berkerja di tempat yang jauh, sehingga perempuan kepala keluarga lebih memilih bekerja di sekitar tempat tinggal sembari dapat memberikan perhatian terhadap keamanan anak-anak di keluarganya, agar tidak terjerumus dalam pergaulan bebas.

\section{Faktor Keberagamaan Perempuan Kepala Keluarga}

Pelaksanaan ajaran agama perempuan kepala keluarga dilaksanakan dengan baik. Ibadah sholat, puasa, zakat menjadi bagian dari pengamalan keberagamaan perempuan kepala keluarga. Pelaksanaan ibadah wajib bagi umat Islam dilaksanakan perempuan kepala keluarga sesuai dengan petunjuk syariat Islam yakni lima waktu dalam sehari semalam dan dilaksanakan berjamaah bersama keluarga. Selain itu pelaksanaan ibadah sholat wajib 5 waktu dilaksanakan di rumah secara berjamaah dan di masjid. Bagi perempuan kepala keluarga pelaksanaan ajaran agama sebagaimana sholat, puasa dan zakat menurut mereka menjadi suatu kewajiban setiap muslim. Hal ini dilakukan dengan penuh kesadaran. Meski dalam kondisi ekonomi yang kurang berkecukupan, dengan latar belakang pendidikan yang minim, namun tidak menjadi penghalang bagi perempuan kepala keluarga untuk meninggalkan kewajiban mereka. Karena itu, dengan sungguh-sungguh perempuan kepala keluarga berupaya menyempatkan waktu mereka untuk, mengerjakan sholat, puasa dan membayar zakat.

Karena itu, sikap keberagamaan perempuan kepala keluarga yang taat melaksanakan sholat adalah sejalan dengan apa yang dikehendaki Allah SWT dengan firman Allah SWT surat ke: 19 ayat 59 yang artinya:

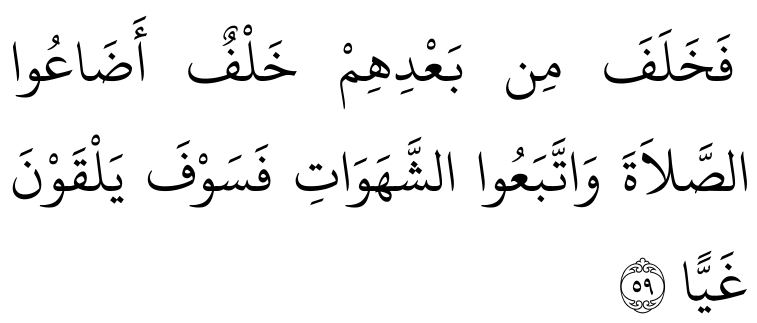

"Maka datanglah sesudah mereka, pengganti (yang jelek) yang menyia-nyiakan shalat dan memperturutkan hawa nafsunya, maka kelak mereka akan menemui kesesatan" (QS. 19:59) 
Demikian juga dengan firman Allah SWT yang menyebut bahwa mengerjakan sholat memerlukan kesungguhan hati dan sebagai suatu kewajiban. Seperti yang tersurat dalam Al-qur'an surat Lukman ayat 17 yang berbunyi:

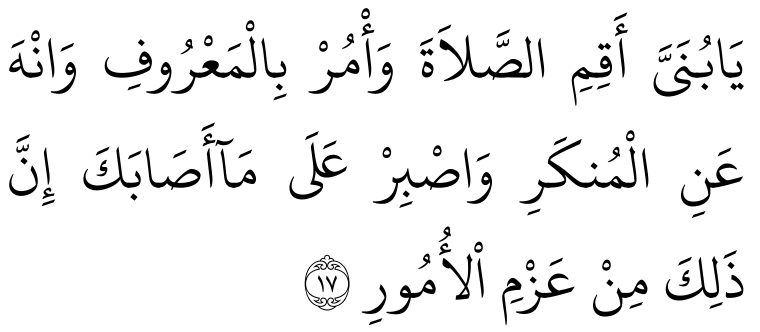

"Hai anakku, dirikanlah shalat dan suruhlah (manusia) mengerjakan yang baik dan cegahlah (mereka) dari perbuatan yang mungkar dan bersabarlah terhadap apa yang menimpa kamu.Sesungguhnya yang demikian itu termasuk hal-hal yang diwajibkan (oleh Allah)" (QS. 31:17)

Merujuk pada al-quran bahwa pelaksanaan ibadah puasa merupakan kewajiban bagi umat Islam sebagaimana yang diatur dalam Al-qur'an Surat Albaqarah 183-184 yang atinya:

"Hai orang-orang yang beriman, diwajibkan atas kamu berpuasa sebagaimana diwajibkan atas orang-orang sebelum kamu agar kamu bertaqwa. (QS. 2:183) (yaitu) dalam beberapa hari yang tertentu. Maka jika di antara kamu ada yang sakit atau dalam perjalanan (lalu ia berbuka), maka (wajiblah baginya berpuasa) sebanyak hari yang ditinggalkan itu pada hari-hari yang lain. Dan wajib bagi orang-orang yang berat menjalankannya (jika mereka tidak berpuasa) membayar fidyah, (yaitu) memberi makan seorang miskin. Barangsiapa yang dengan kerelaan hati mengerjakan kebajikan, maka itu lah yang lebih baik baginya. Dan berpuasa lebih baik bagimu jika kamu mengetahui. (QS. 2:184).
Melalui sikap keberagamaan yang tercermin dalam pelaksanaan ajaran agama dalam segala kondisi, maka dari sini wujudnya kepatuhan kepada Allah SWT dari perempuan kepala keluarga dalam menjalan syariat Islam. Dalam firman Allah SWT surat Al-Mulk ayat 16 berbunyi dan Q.S. Al Baqarah: 208

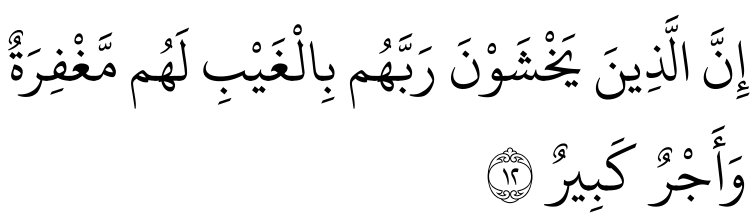

"Sesungguhnya orang-orang yang takut kepada Rabbnya Yang tidak tampak oleh mereka, mereka akan memperoleh ampunan dan pahala yang besar. (QS. $67: 12)$
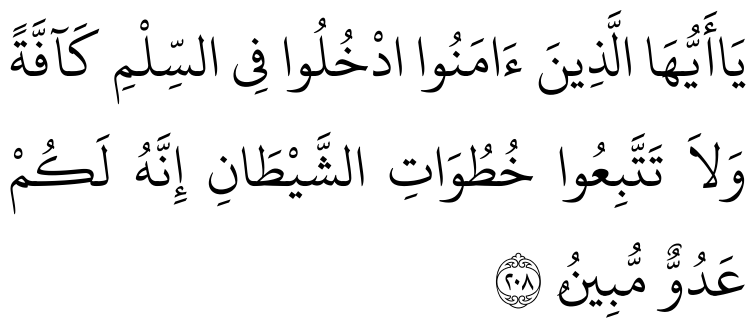

"Hai orang-orang yang beriman, masuklah kamu ke dalam Islam keseluruhan, dan janganlah kamu turut langkah-langkah syaitan. Sesungguhnya syaitan itu musuh yang nyata bagimu"(Q.S. Al Baqarah:208)

Adapun pelaksanaan zakat yang telah dilakukan oleh perempuan kepala keluarga merupakan ibadah kebendaan yang menjadi perhatian Islam. Yaitu, agar orang yang kaya memberikan pertolongan kepada yang miskin, berupa sesuatu yang dapat menutupi kebutuhannya, atau memberikan sesuatu yang dapat mendatangkan kemaslahatan bagi masyarakat luas. 
Kewajiban zakat merupakan terhadap ajaran agama Islam tercermin bentuk nyata dalam tatanan ubudiyah. dalam perilaku kehidupannya sehari-hari Kewajiban zakat maupun sedekah dan yang bersumber dari peran orang tua, jauh jariah mengandung arti dorongan bagi umat Islam untuk mewujudkan kesejahteraan masyarakat, peduli kepada sesama dan mendorong untuk memiliki etos kerja produktif dan bersikap mandiri. Dalam ajaran Islam, sikap yang demikian tentunya menjadi ladang amal bagi perempuan kepala keluarga yang di hari kemudian menjadi pahala baginya.

\section{Pendidikan Orang Tua Dalam keluarga}

Bagi Glock dan Stark dalam (Asep Iwan Setiawa, 2011) mengidentifikasi perilaku keagamaan (Religiusitas) melalui: (1). Ritual Involvement (Keterlibatan ritual). Individu melakukan peribadatan secara ritual. seperti shalat, puasa, membayar zakat, dan sebagainya (2) Involvement (Keterlibatan Ideologis) yaitu upaya mempertahankan keyakinan dan memiliki cita-cita tertentu sesuai dengan keyakinan yang dipegang (3) Intellectual involvement (keterlibatan intelektual) upaya mempelajari segala hal tentang agama yang diyakini (4) oriental involvement (keterlibatan pengalaman). Perilaku keagamaan yang intuitif atau lahiriah (5).Consequential involvement, (keterlibatan secara konsekuensial). Keseharian seseorang melakukan kebaikan atau sebaliknya.

Berdasarkan kajian ini,
keberagamaan perempuan kepala keluarga sebelum perempuan kepala keluarga berumah tangga. Selain itu, sebagian lagi diperkuat lagi dengan pigur suami semasa hidup bersama sejak suami masih hidup bersama. Penanaman nilai-nilai ajaran Islam tentang ibadah seperti sholat, puasa, zakat dan lainnya telah diterima perempuan dari orang tua dan bimbingan suaminya. Pendidikan agama dalam keluarga telah digariskan dalam al-quran QS: Attahrim: 6 "Hai orang-orang yang beriman, peliharalah dirimu dan keluargamu dari api neraka yang bahan bakarnya adalah manusia dan batu; penjaganya malaikat-malaikat yang kasar, yang keras, yang tidak mendurhakai Allah terhadap apa ang diperintahkan-Nya kepada mereka dan selalu mengerjakan apa yang diperintahkan" (QS. 66:6).

Sebagai figur utama memberikan perempuan kepala keluarga mempunyai pengaruh positif pada keluarga; pada anakanak hingga cucu. Sebab kebiasaan untuk menunaikan sholat berjamaah, membaca al-quran telah dikenalkan sejak awal, setiap hari dalam keluarga hingga berumah tangga sehingga pendidikan di keluarga menjadi bekal melalui kehidupan berumah tangga bagi generasi berikutnya.

\section{E. Pengaruh Lingkungan}

1. Lembaga Dakwah (Majelis Taklim) Dalam Undang-Undang RI No.20 Tahun 2003 tentang sistem Pendidikan 
Nasional dan Peraturan Pemerintah no 55 tahun 2007. Undang-Undang RI No.20 Tahun 2003 dinyatakan bahwa jalur pendidikan terdiri dari tiga yaitu formal, informal dan jalur non formal yang biasanya dilaksanakan oleh Lembaga kursus, Pelatihan, Kelompok Belajar, PKBM, Majlis Ta'lim dan lain-lain. Majelis taklim memiliki dua fungsi sekaligus, yaitu sebagai lembaga dakwah dan lembaga pendidikan nonformal. Fleksibelitas majelis taklim inilah yang menjadi kekuatan sosial keagamaan ummat Islam memberi warna dinamis masyarakat yang ada di sekitar majelis taklim, sehingga partisipasi ummat lebih maksimal. Dengan demikian majelis taklim menjadi lembaga pendidikan ibadah yang terdekat bagi mereka yang tidak memiliki cukup tenaga, waktu, dan kesempatan menimba ilmu agama dijalur pandidikan formal.

Terbentuknya sikap keberagamaan perempuan kepala keluarga, dibangun oleh pengetahuan yang mereka terima dari lembaga dakwah yakni majelis taklim yang ada di sekitar tempat tinggal. Pengajian yang digelar majelis taklim memotivasi perempuan kepala keluarga untuk memiliki pengetahuan tentang bagaimana memahami dan menjalankan ajaran Agama Islam dan menjadi muslim yang baik. Faktor lingkungan dalam hal ini adanya majelis taklim di sekitar perempuan kepala keluarga mendorong kesadaran untuk menjalankan kehidupan sesuai dengan ajaran agama Islam. Majelis taklim yang ada di sekitar lingkungan perempuan kepala keluarga yakni menjadi media pembelajaran. Keberadaan majilis taklim yang ada di sekitar tempat tinggal, menjadi salah satu sarana bagi perempuan kepala keluarga mengembangkan dirinya secara pribadi dalam rangka menjaga diri dan keluarga dari berbagai pengaruh negatif. Kehadiran perempuan dalam aktivitas majelis taklim, sekaligus menjadi upaya memelihara atau menjaga keberagamaan perempuan kepala keluarga.

\section{Masjid sebagai pusat kegiatan ummat Islam}

Masjid dengan beragam fungsinya diamanatkan bagi kepentingan ummat Islam. Kegiatan keagamaan ummat Islam sekitar, telah menjadi salah satu sumber pendorong perempuan untuk mengenal ajaran Islam dan lebih dekat dengan pencipta-Nya. Adapun kegiatan yang diikuti di masjid seperti mengaji al-quran setiap sholat magrib, maupun kultum (kuliah 7 menit) selepas magrib ataupun kulsub (kuliah subuh) yang dilaksanakan selepas sholat shubuh. Seperi di masjid Jami' dan beberapa masjid lainnya di Pontianak Timur. Mengikuti pengajian yang digelar pengurus masjid setiap minggu dan kegiatan lainnya. Hadirnya Adanya lembaga dakwah sendiri mempunyai tujuan antara lain, berusaha dan bergerak pada bidang dakwah yang dilakukan mempunyai susunan yang teratur untuk mencapai 
tujuan dengan cara yang baik dan tepat Wajidi Sayadi (2014).

\section{F. Kesimpulan}

Keberagamaan perempuan

kepala keluarga tercermin dalam pelaksanaan ajaran Islam dalam kehidupan sehari-hari. Sebagaimana penulis peroleh bahwa perempuan kepala keluarga melaksanakan ibadah sholat, puasa dan menunaikan zakat. Hal lainnya yang dilakukan perempuan kepala keluarga berperilaku peduli pada sesama seperti dengan mengajar anak-anak di sekitar tempat tinggal mengaji al-qur'an dan memberi sedekah. Selain itu, perempuan kepala keluarga juga bermasyarakat. Sikap keberagamaan yang dimiliki perempuan kepala keluarga berlangsung dalam keadaan yang secara kasat mata sulit. Dalam artian, latar belakang pendidikan yang hanya Sekolah Dasar dan keadaan ekonomi yang pas-pasan dengan pekerjaan sebagai buruh. Disamping itu, dinamika kehidupan perempuan kepala keluarga yang ditinggal oleh suami baik ditnggal karena meninggal dunia maupun bercerai, perempuan kepala keluarga masih dapat bertahan.

Perempuan kepala keluarga tidak menjadi putus asa menjalani kehidupannya selepas kematian suami atau bercerai. Selain itu, perempuan kepala keluarga tetap bertanggungjawab tanpa memikirkan kepentingannya sendiri dengan kata lain lebih memikirkan untuk menikah lagi, sebaliknya perempuan kepala keluarga dapat menjalankan perannya sebagai ibu rumah tangga sekaligus kepala keluarga dalam membesarkan anak-anak dan mengurus saudaranya. Perempuan kepala keluarga berupaya memelihara amanat yang diberikan tuhan kepadanya, sehingga kebutuhan dan pendidikan anak-anak perempuan kepala keluarga tidak terabaikan. Hal menarik dari penelitian ini, sikap keberagamaan perempuan kepala keluarga di pengaruhi oleh beberapa faktor yakni (1) Pendidikan Orang Tua Dalam keluarga; (2) Lembaga Dakwah (Majelis Taklim); (3) Pengaruh Lingkungan Masjid. Upaya perempuan kepala keluarga menjaga keberagamaannya, mereka tidak berdiam diri, selain karena faktor usia perempuan kepala keluarga yang tidak muda lagi. Perempuan kepala keluarga mengupayakan agar agama dapat berfungsi optimal bagi kehidupan manusia, yaitu dapat menimbulkan perilaku yang positif (bekerja keras, mandiri dan peduli pada sesama serta bermanfaat bagi lingkungan sekitar) dan mencegah perilaku yang negatif. Karenakan perempuan kepala keluarga mematuhi ajaran orang tua. Figur orang tua meski sudah tidaklagi tinggal bersama dengan perempuan kepala keluarga namun tetap menjadi rujukan. Dalam artian, ajaran atau pendidikan agama yang telah diajarkan dalam keluarga sebelum menikah telah menjadi pedoman dalam menjalankan kehidupan perempuan kepala keluarga berumah tangga. 


\section{G. Daftar Pustaka}

Asep Setiawan. 2011. Efektivitas Dakwah

Fiah: Studi Model Lembaga Dakwah

Kampus. Jurnal IImu Dakwah. Vol. 5

No. 2 Edisi Juli - Desember

Bryan S. Turner. 2012. Relasi Agama dan

Teori. Jogjakarta: IRCiSoD

Cate Sumner 2010. Penelitian akses dan kesetaraan. Autralia Legal

Development (IALDF)

Departemen agama RI. 1997. Al-qur'an dan

Terjemahan. Jakarta: Proyek

Pengadaan Kitab Suci Al--quran

Djalaludin Rahmat, 1989. Metodologi

Penelitian Agama Sebuah

pengantar. Yogayakarta: Tiara

Wacana,

Haitami Salim. 2013. Pendidikan Agama Dalam

Keluarga. Yogyakarta: Ar-Ruzz Media

Harjani Hefni. 2012. Peran Agama, Dakwah,

Dan Dai dalam Membangun

Manusia Yang Berkarakter. Jurnal Al-Hikmah, Vol. VI

Nur Azizah, 2006. Perilaku Moral dan

Religiusitas

Siswa

Berlatar Belakang Pendidikan

Umum dan Agama. Jurnal Psikologi.

Vol.33 no 2 h. 1-16

Organisasi Perempuan Kepala Keluarga

Pekka: http//www//pekka.or.id.

Diakses 2 Februari 2015

Perempuan Kian Berani Gugat Cerai.

(Online: http/www//m.equator-

news.com diakses tanggal 15

Februari 2012).
Profil Kecamatan Pontianak Timur Tahun 2014.

Rachmat Kriyantono. 2006. Teknis Praktis Riset Komunikasi. Jakarta: Kencana Prenada Media Grup

Sekar Ayu Aryani, 2015. Orientasi, Sikap dan Perilaku Keagamaan. Religi, Vol. XI, No. 1, Januari 2015: 59-80

Siska Sasmita. 2011. Peran Perempuan Suku Minangkabau yang Menjadi Kepala Keluarga (PEKKA) Bagi Penciptaan Ketahanan Pangan Rumah Tangga di Kecamatan Padang Timur. Jurnal Humanis. Vol $X$ no I

Sugiyono, (2011). Metodologi Penelitian Kuantitatif, Kualitatif dan $R$ \& $D$. Bandung: Penerbit Alfabeta.

Ugm.co.id. Tahun 2008. (Online: diakses 10 Februari 2013.

Undang-Undang Dasar 1945 Bab XI pasal 29 (1) dan (2)

Wajidi Sayadi. 2014. Makalah Kapasistas Lembaga Dakwah dalam Membangun Keluarga. Disampaikan Acara Pelatihan Pengembangan Diri Perempuan Kampung Beting Berbasis Lembaga Dakwah di Kota Pontianak, Minggu, 30 Nopember 2014

W.J.S Poerwadarminta. 1990. Kamus Besar Bahasa Indonesia. Jakarta: Balai Pustaka

http://pontianak.tribunnews.com/2016/03/0 5/tahun-2015-sebanyak-2450- 
wanita-di-pontianak-menjanda

diakses desember 2016

http://equator.co.id/janda-pontianak-

karena-gugat-cerai-

meningkat/diakses juni 2017 